\title{
STUDI EVALUASI ATAS DANA TALANGAN HAJI PRODUK PERBANKAN SYARIAH DI INDONESIA
}

\author{
Sopa \& Siti Rahmah \\ Fakultas Agama Islam Universitas Muhammadiyah Jakarta \\ Jl. K.H. Ahmad Dahlan, Ciputat, Jakarta Selatan, 15419 \\ E-mail: sopadr2008@yahoo.co.id; rahma_faiumj@yahoo.co.id
}

\begin{abstract}
An Evaluation Study on Haji Bridging Funds of Shariab Banking Products in Indonesia. Hajj bridging funds are one of the financing products of Islamic banking based on a fatwa of the National Shariah Council that was endorsed by the Ijtimak Ulama of Fatwâ Commission throughout Indonesia. The bridging funds are to be provided to the customers who are able to settle up the loan before the hajj. Different transactions are used in hajj bridging funds. There are transactions of ijârah, qard, or both. Hajj bridging funds provide a positive impact (maslahah) like the ease for customers to obtain the hajj departure portion. However, the disadvantage (mafsadah) of hajj bridging funds are the increasing waste of the criteria of ability (istiț $\hat{a}^{\prime} a h$ ) in hajj and the extending of hajj departure waiting lists.
\end{abstract}

Keywords: hajj bailout, istitâ'ah, masla $\underline{h} a h$, transaction of ijârah, transaction of qard

Abstraks: Studi Evaluasi atas Dana Talangan Haji Produk Perbankan Syariab di Indonesia. Dana talangan haji merupakan salah satu produk pembiayaan perbankan syariah yang berlandaskan fatwa Dewan Syariah Nasional yang diperkuat oleh Ijtimak Ulama Komisi Fatwa seluruh Indonesia. Dana talangan haji diberikan kepada nasabah yang mampu melunasinya sebelum melaksanakan ibadah haji. Akad yang digunakan dalam talangan haji berbeda-beda. Ada yang menggunakan akad ijârah, qard, dan gabungan keduanya. Dana talangan haji memberikan dampak positif (maslabah) berupa adanya kemudahan kepada nasabah untuk mendapatkan porsi keberangkatan haji. Sedangkan dampak negatif (mafsadah) dana talangan haji adalah semakin mengaburkan kriteria mampu (istitấah) dalam haji dan memperpanjang daftar tunggu keberangkatan haji.

Kata Kunci: dana talangan haji, istitấah, maslahah, akad ijârah, akad qard

\section{Pendahuluan}

Muhammad Busyro Muqaddas, Wakil Ketua KPK, adalah orang yang pertama kali mengusulkan perlunya moratorium pendaftaran haji. Usulan ini kemudian disetujui oleh Ikatan Persaudaraan Haji Indonesia (IPHI). Busyro mengkhawatirkan dana yang menumpuk begitu banyak hingga 32 trilyun di rekening Menteri Agama akan disalahgunakan atau dikorupsi oleh pihak-pihak yang tidak bertanggung jawab. Sebab, manajemen pendaftaran calon jamaah haji yang selama ini berjalan sangat rawan untuk dikorupsi. Oleh karena itu, selama belum ada perbaikan manajemen maka sebaiknya Kementerian Agama menghentikan sementara pendaftaran haji ${ }^{1}$. Kekhawatiran tersebut

Naskah diterima: 21 Maret 2013, direvisi: 27 Mei 2013, disetujui untuk terbit: 7 Juni 2013.

1 Http://news.detik.com/read/2012/02/21/181538/1848242/10/ berpotensi-korupsi-kpk-usulkan moratorium-pendaftaran-haji, diunduh pada 23 Desember 2012. wajar karena begitu mengguritanya korupsi di negara Indonesia saat ini.

Selanjutnya, ketua umum IPHI, Kurdi Mustofa, menyampaikan fakta bahwa pendaftaran ibadah haji yang berlaku selama ini telah mengakibatkan penumpukan pendaftar dalam jumlah yang sangat besar yaitu mencapai 1,6 juta orang. Oleh karena itu, manajeman ibadah haji perlu ditata ulang dengan terlebih dahulu memberlakukan moratorium. Setelah itu baru diberlakukan sistem pendaftaran buka-tutup sesuai dengan jatah kuota haji yang diperoleh dari pemerintah Arab Saudi².

Sementara itu, tidak sedikit pihak-pihak yang tidak setuju dengan usulan tersebut, di antaranya wakil rakyat di DPR. Hasrul Azwar dari Komisi VIII, misalnya, berkeberatan dengan moratorium karena tidak dapat menyelesaikan masalah, bahkan bisa menimbulkan

2 Http://news.detik.com/read/2012/02/21/181538/1848242/10/ berpotensi-korupsi-kpk-usulkan moratorium-pendaftaran-haji, diunduh pada 23 Desember 2012. 
masalah baru yang tidak kalah peliknya. Pemerintah tidak bisa menghentikan pendaftaran calon jamaah haji karena pendaftaran haji menjadi hak calon jamaah haji. ${ }^{3}$

Menanggapi usulan ini, Suryadharma Ali, selaku Menteri Agama, memberikan tanggapan bahwa jika pendaftaran haji dihentikan maka dana calon jamaah yang sudah terkumpul harus dikembalikan semuanya sehingga tidak ada uang yang tersimpan di rekening Menteri Agama. Akibatnya, biaya perjalanan haji akan menjadi mahal karena akan mengalami kenaikan yang bisa mencapai Rp 40 juta per jamaah akibat tidak ada dana subsidi dari bunga simpanan. Di samping itu, jika sistem daftar tunggu dihilangkan dan kemudian menggunakan sistem buka-tutup pendaftaran sesuai dengan kuota yang tersedia, maka kuota yang ada akan menjadi rebutan banyak orang mengingat antusias umat Islam untuk berangkat haji sangat tinggi. ${ }^{4}$

Adapun Ketua Komnas HAM, Ifdal Kasim, memberikan respons positif terhadap usulan KPK. Menurut dia, apabila moratorium itu bisa membuat penyelenggaraan haji lebih baik dan mengurangi korupsi maka hal tersebut bisa dilakukan karena tidak melanggar Hak Asasi Manusia (HAM), sebab moratorium itu tidak mencabut hak untuk beragama. Guna melindungi kepentingan yang lebih besar pemerintah boleh melanggar hak-hak tersebut, apalagi jika langkah antisipasif ini tidak dilakukan maka akan menimbulkan kerugian yang lebih besar bagi calon jamaah haji. ${ }^{5}$

Ketua Majelis Ulama Indonesia (MUI) Pusat, K.H. Ma'ruf Amin, berpendapat bahwa usulan moratorium perlu dikaji lebih mendalam yaitu perlu dikaji keuntungan (maslahah) dan kerugiannya (madârat). Lebih dari itu, kajian ini juga harus dilakukan terhadap faktor-faktor penyebab yang mengakibatkan calon jamaah haji waiting list mencapai 1,6 juta orang. Hal ini penting dilakukan agar dapat ditemukan akar masalahnya kemudian dicarikan jalan keluar.

Dugaan sementara penumpukan daftar tunggu itu disebabkan oleh beberapa faktor, di antaranya adalah meningkatnya kesejahteraan umat Islam yang ditandai dengan meningkatnya pendapatan mereka. Di samping itu, adanya jasa dana talangan haji yang diberikan oleh

${ }^{3} \mathrm{p} /$ arsip-berita-nasional/75-nasional-reviews/21934-komisi-viiikritik-busyro-soal-moratorium-haji.html, diunduh pada 23 Desember 2012.

${ }^{4}$ Http://news.detik.com, diunduh pada 23 Desember 2012.

${ }^{5}$ Http://www.hariansumutpos.com/2012/02/27081/daftar-hajitunggu-8-tahun-lagi.htm, diunduh pada 23 Desember 2012.

${ }^{6}$ 2/02/27081/daftar-haji-tunggu-8-tahun-lagi.htm, diunduh pada 23 Desember 2012. perbankan syariah untuk membantu calon jamaah yang mengalami kesulitan untuk mendaftar haji juga berpengaruh pada penumpukan daftar tunggu tersebut.

Pada awalnya, calon jamaah bisa mendaftar dan berangkat haji pada tahun yang sama. Selanjutnya terjadi pergeseran yang menimbulkan antrean atau daftar tunggu, mulai satu tahun kemudian menjadi dua tahun bahkan ada yang sampai 10 tahun. Berdasarkan jumlah daftar tunggu yang mencapai 1,6 juta orang bisa diprediksi bahwa rata-rata mereka menunggu keberangkatan ibadah hajinya sekurang-kurangnya delapan tahun jika kuota haji tetap 200 ribu orang per tahun.

Apabila benar bahwa dana talangan haji menjadi salah satu sebab penumpukan daftar tunggu maka sebenarnya jamaah tersebut belum dikategorikan mampu untuk beribadah haji. Karena ketika Nabi Muhammad Saw. ditanya tentang apa yang dimaksud istitâ'ah, beliau menjawab, "al-Zâd wa al-râhilah", yaitu bekal dan perjalanan yang saat ini disebut Biaya Perjalanan Ibadah Haji (BPIH). Apabila sebagian besar BPIH diperoleh dari dana talangan haji berarti jamaah yang memanfaatkannya termasuk dalam kategori "miskin" sehingga tradisi "haji miskin" yang sudah lama terjadi sejak zaman penjajah Belanda masih tetap eksis sebagaimana disinyalisasi oleh M. Saleh Putuhena ${ }^{8}$.

Di sisi lain, dana talangan haji ini direstui oleh para ulama yang ada di Dewan Syariah Nasional Majelis Ulama Indonesia (DSN-MUI) dalam bentuk fatwa? Kementerian Agama juga menerima pendaftaran calon jamaah haji dengan dana yang bersumber dari utang berupa dana talangan haji. Dengan demikian, berarti fatwa tersebut secara tidak langsung menganggap calon jamaah tersebut sudah istitâah, yaitu mampu untuk membayar cicilan sehingga laik dikategorikan istitâ'ah potensial.

Konsep awalnya, dana talangan haji tersebut diberikan kepada umat Islam untuk memberikan kemudahan dalam pendaftaran haji. Tetapi kemudian justru menimbulkan dampak yang cukup pelik yaitu penumpukkan calon jamaah haji dan antrean keberangkatan yang begitu panjang. Berdasarkan hal itu, maka perlu dilakukan kajian untuk mengevaluasi

${ }^{7}$ Al-Tirmîdhî, Sunan al-Tirmîdhî, juz III, (Bayrût : Dâr al-Fikr, 2003), h. 219.

${ }^{8}$ M. Shaleh Putuhena, Historiografi Haji Indonesia, (Yogyakarta: LkiS, 2007), h. 147,164, dan 165.

${ }^{9}$ Lihat Fatwa DSN No.29/DSN-MUI/VI/2002 tentang Pembiayaan Pengurusan Haji Lembaga Keuangan Syariah, No.09/DSN-MUI/ IV/2000 tentang Pembiayaan Ijârah dan No.19/DSN-MUI/IV/2001 tentang al-Qard. 
kebijakan tersebut baik menyangkut aspek sharî̀ yang menjadi landasan hukumnya maupun dampak yang ditimbulkannya.

\section{Argumen Dana Talangan Haji}

Landasan shar'î produk perbankan syariah dana talangan haji adalah fatwa DSN-MUI, sebab masalah tersebut tidak ada ketentuannya dalam teks Alquran dan Hadis yang merupakan sumber utama hukum Islam. Hal ini juga tidak pernah dibahas oleh ulamaulama klasik sebagaimana terdapat dalam literatur kitab-kitab kuning. Oleh karena itu, masalah tersebut termasuk masalah baru sehingga menjadi objek ijtihad. Dengan perkataan lain, termasuk masalah ijtihâdiyyah.

Jasa dana talangan haji dibutuhkan oleh umat Islam sehingga perlu diakomodasi oleh perbankan syariah. Operasional perbankan syariah harus sesuai dengan prinsip-prinsip syariah. Pihak perbankan syariah mengajukan permohonan fatwa kepada DSN-MUI sehingga lahirlah fatwa Nomor: 29/DSN-MUI/VI/2002 yang menjadi landasan sharî̀ dana talangan haji. Diktum fatwa tersebut secara lengkap berbunyi: (1) Dalam pengurusan haji bagi LKS dapat memperoleh imbalan jasa (ujrah) dengan menggunakan prinsip al-ijârah sesuai Fatwa DSN-MUI No.9/DSN-MUI/IV/2000. (2) Apabila diperlukan, LKS dapat membantu menalangi pembayaran BPIH nasabah dengan menggunakan prinsip al-qard sesuai Fatwa DSN-MUI No.19/DSNMUI/IV/2001. (3) Jasa pengurusan haji yang dilakukan LKS tidak boleh dipersyaratkan dengan pemberian talangan haji. (4) Besar imbalan jasa al-ijârah tidak boleh didasarkan pada jumlah talangan al-qard yang diberikan LKS kepada nasabah. ${ }^{10}$

Fatwa tersebut kemudian dikukuhkan oleh Ijtimak Ulama Komisi Fatwa seluruh Indonesia yang diselenggarakan di Cipasung, Tasikmalaya, tahun 2012.

Berdasarkan uraian tersebut maka jelas bahwa landasan shar'î dana talangan haji adalah fatwa ulama. Hal ini tidak mengurangi keabsahan produk tersebut dalam tinjauan hukum Islam karena fatwa ulama bisa mengisi kekosongan landasan sharî̀ ketika Alquran dan Hadis tidak menetapkannya secara eksplisit (mansûsah). Sebab ulama dalam Islam berdudukan sebagai pewaris para nabi (warathah al-anbiyâ) dan dapat berfungsi sebagai pembuat hukum (shâr $\hat{\imath})$ ketika Allah (Alquran) dan Rasul-Nya (Hadis) tidak memberikan ketetapan

\footnotetext{
${ }^{10}$ Ikhwan Sam, et. al., Himpunan Fatwa Dewan Syariah Nasional, edisi revisi, (Jakarta: Dewan Syariah Nasional MUI dan Bank Indonesia, 2006), h. 176.
}

hukum yang jelas dan pasti (sârîh).

Kewenangan ulama sebagai pembuat hukum Islam tidak bebas berdasarkan ra'y atau akal fikiran manusia semata, tetapi harus tetap merujuk pada nas, baik Alquran maupun Hadis Nabi Saw. Oleh karena itu, fatwa-fatwa ulama tersebut mempunyai landasan shar'î yang kuat karena merujuk pada nas Alquran dan Hadis maupun qawầid al-fiqhiyyah.

Fatwa DSN Nomor: 29/DSN-MUI/VI/2002 mempunyai rujukan sebagai berikut: ${ }^{11}$ Pertama, dari Alquran antara lain Q.s. al-Mầidah [5]: 1 tentang akad, Q.s. alQasas [28]: 26 tentang ijârah, Q.s. al-Baqarah [2]: 282 tentang utang piutang, Q.s. al-Baqarah [2]: 280 tentang penundaan pelunasan utang, Q.s. al-Mầidah [5]: 2 tentang tolong-menolong dalam kebaikan. Kedua, Hadishadis Nabi Saw., yaitu antara lain: Hadis riwayat 'Abd al-Razzâq dari Abû Hurayrah dan Abû Sa'îd al-Khudrî tentang al-ijârah ${ }^{12}$, Hadis riwayat Muslim dari Abû Hurayrah tentang anjuran menolong orang yang berada dalam kesulitan ${ }^{13}$, Hadis riwayat Jamâah, al-Nasầ̂̂, Abû Dâwud, Ibn Mâjah dan Ahmad tentang larangan menunda-nunda pembayaran utang tanpa alasan yang kuat ${ }^{14}$, Hadis riwayat al-Bukhârî tentang anjuran untuk melakukan pembayaran utang dengan cara yang lebih baik $^{15}$, Hadis riwayat al-Tirmîdhî tentang bolehnya melakukan perjanjian dalam bidang muamalah ${ }^{16}$. Ketiga, qawẩid fiqhiyyah, yaitu antara lain kaidah, "Pada dasarnya semua bentuk muamalah itu boleh dilakukan kecuali ada dalil yang mengharamkannya"17; "Kesulitan dapat menarik kemudahan"18, "Keperluan dapat menduduki posisi darurat" 19

Ijtimak Ulama Komisi Fatwa Majelis Ulama seluruh Indonesia memperkuat fatwa tersebut dengan tambahan

${ }^{11}$ Ikhwan Sam, et. al., Himpunan Fatwa Dewan Syariah Nasional, h. 171-177.

${ }^{12}$ Lihat juga Musannaf Ibn Abî Shaybah dalam Maktabah Shâmilah, juz IV, h. 366.

${ }^{13}$ Imâm Muslim, al-Jâmi' al-Sahîh, juz VII, (Bayrût: Dâr al-Fikr, t.th.), h.18.

${ }^{14}$ Al-Bukhârî, Sahîh al-Bukhârî, jilid II, (al-Qâhirah: Dâr al-Hadîth, 2004), h. 129.

${ }^{15}$ Al-Bukhârî, Sahîh al-Bukhârî, h. 135.

${ }^{16}$ Al-Tirmîdhî, Sunan al-Tirmîdhî, juz III, h. 73.

17 'Alî Ahmad al-Nadwî, Al-Qawâid al-Fiqhiyyah: Mafbûmuhâ, Nash'atuhâ, Tatawwuruhâ, Dirâsah Mu'allafâtuhâ, Adillatuhâ, Muhimmatuhâ, Tatbîquhâ, cet. III, (Damaskus: Dâr al-Qalam, 1994), h. 122 .

18 'Alî Ahmad al-Nadwî, Al-Qawâid al-Fiqhiyyah: Mafhûmuhâ, Nash'atuhâ, Tatawwuruhâ, Dirâsah Mu'allafâtuhâ, Adillatuhâ, Muhimmatuhâ, Tatbîquhâ, h. 394 dan Al-Suyûtî, Al-Ashbah wa alNazẩir fí al-Furû́, (Jakarta: Dâr al-Fikr, t.th), h. 55.

19 Alî Ahmad al-Nadwî, Al-Qawâid al-Fiqhiyyah: Mafhûmuhâ, Nash'atuhâ, Tatawwuruhâ, Dirâsah Mủallafâtuhâ, Adillatuhâ, Muhimmatuhâ, Tatbîquhâ, h. 233 dan Al-Suyûtî, Al-Ashbah wa alNazâiir fî al-Furû', (Jakarta: Dâr al-Fikr, t.th), h. 62. 
argumen. Pertama, teks ayat Alquran yang dijadikan rujukan dalam fatwa tersebut adalah Q.s. Âli 'Imrân [3]: 97 yang menjelaskan ketentuan istitâ'ah dalam ibadah haji. Kedua, Hadis Nabi Saw. yaitu Hadis riwayat alTirmîdhî dan al-Dâruqutnî yang menjelaskan tentang istitâah itu meliputi perbekalan dan kendaraan ${ }^{20}$. Ketiga, âthâr Sahabat tentang praktik haji menggunakan dana hasil pinjaman yang diperbolehkan dan yang dilarang. Keempat, qawầid fiqhiyyah, "Sarana suatu perbuatan itu dihukumi sama dengan maksud/tujuannya" dan "Setiap perkara tergantung pada tujuannya"21. Kelima, pendapat Imâm Shâf'îyang menyatakan bahwa siapa saja yang tidak memiliki kelebihan harta yang membuatnya laik untuk menunaikan ibadah haji tanpa melakukan pinjaman, maka orang tersebut dianggap tidak terkena kewajiban haji karena termasuk orang tidak berkemampuan. Tetapi jika ia mempunyai harta yang banyak maka ia dapat menjual sebagiannya atau berutang dengan keyakinan dapat membayar utang tersebut serta mempunyai harta yang bisa dicadangkan".

Selain itu ada juga pihak-pihak yang tidak setuju dengan dana talangan haji. Pertama, organisasi keagamaan Persatuan Islam (PERSIS). Menurut Irvan Safrudin, Sekretaris Umum Pimpinan Pusat PERSIS, Sidang Dewan Hisbah PERSIS merekomendasikan agar pemerintah menghentikan praktik dana talangan haji karena haram. Sebab, dana talangan tersebut mengganggu sistem pembinaan umat. Ibadah haji pada prinsipnya tidak dipaksakan namun berdasarkan kemampuan. Kalau seseorang belum mampu untuk menunaikan ibadah haji maka tidak perlu dipaksakan atau didorong dengan menggunakan dana talangan dari perbankan. ${ }^{22}$ Dengan perkataan lain, PERSIS mengharamkan dana talangan haji karena nasabah tersebut sebenarnya belum istitâ'ah sehingga belum terkena kewajiban haji ${ }^{23}$.

Kedua, Hizbut Tahrir Indonesia (HTI) melarang dana talangan tersebut. Menurut HTI, fatwa DSNMUI tentang dana talangan haji yang menggunakan akad al-ijârah tidak tepat, sebab kenyataannya dana talangan haji adalah utang-piutang (qard), di mana perbankan syariah memberikan dana talangan (qard) kepada calon jamaah haji agar bisa mendapatkan nomor

${ }^{20}$ Al-Tirmîdhî, Sunan al-Tirmîdhî, h. 219.

${ }^{21}$ Al-Suyûtî, Al-Ashbah wa al-Nazẩir fì al-Furû, (Jakarta: Dâr al-Fikr, t.th), h. 6.

${ }^{22}$ Koran Harian Umum Republika, 20 Nopember 2012.

${ }^{23}$ Bandingkan dengan Jaih Mubarok dan Hasanudin, "Fatwa tentang Pembiayaan Pengurusan Dana Haji dan Status Dana Calon Haji Daftar Tunggu", dalam Al-Iqtishad, Jurnal Ilmu Ekonomi Syariah, Fakultas Syariah dan Hukum kerjasama dengan Ikatan Ahli Ekonomi Islam Indonesia, Vol. V, No. 1, Januari 2013, h. 29. porsi haji. Dengan begitu maka posisi calon jamaah haji berutang kepada bank. Oleh karena itu maka ditetapkan syarat agar calon jamaah yang bersangkutan harus sudah melunasi utangnya sebelum melaksanakan ibadah haji. Hal ini membuktikan bahwa akad dana talangan ini jelas merupakan akad utang-piutang (qard), bukan akad al-ijârah. Apalagi nilai nominalnya jelas dan bersifat (fxed), di mana oleh para fukaha disebut (qard), bukan (dayn), sehingga harus dibayar dengan nilai nominal yang sama, tidak boleh lebih atau adanya tambahan dari pokok utang. ${ }^{24}$

Dalam berbagai kitab fikih disebutkan bahwa cakupan akad (ijârah) meliputi tiga kategori yaitu: (1) Ijârah terhadap orang (Ijârah al-Shakhs) seperti mengontrak pembantu. (2) Ijârah terhadap pekerjaan (Ijârah al-Shakhs) seperti mengontrak jasa dokter dan insinyur. dan (3) Ijârah terhadap barang (Ijârah al-Ayn) seperti menyewa mobil, rumah, dan sebagainya. ${ }^{25}$ Dari ketiga kategori tersebut, kegiatan yang dilakukan oleh perbankan syariah untuk meminjamkan dana kepada calon jamaah haji tidak termasuk di dalamnya. Istilah ‘jasa meminjami’ yang digunakan sebagai justifikasi untuk menyamakan jasa ini dengan jasa (al-manfáah) yang menjadi objek akad ijarah jelas tidak tepat dan menyesatkan, sebab faktanya 'jasa' ini adalah fakta utang-piutang (qard), bukan ijârah. ${ }^{26}$

Ketiga, Ahmad Zain An-Najah. Dalam praktiknya, perbankan syariah menawarkan dana talangan haji kepada nasabah yang belum mempunyai dana yang cukup untuk biaya haji dengan ketentuan bahwa pihak bank yang akan mengurus pendaftaraan haji dan meminta upah kepada nasabah. Dengan demikian, pihak bank telah melanggar ketentuan umum No. 3 Fatwa DSN yang berbunyi, "Jasa pengurusan haji yang dilakukan Lembaga Keuangan Syariah (LKS) tidak boleh dipersyaratkan dengan pemberian talangan haji”. Oleh karena itu, secara syariat praktik seperti ini tidak diperbolehkan dengan alasan Hadis riwayat Abû Dâwud dan al-Tirmîdhî dari 'Abd Allâh ibn 'Amr R.a. tentang tidak diperbolehkannya pinjaman yang disyaratkan dengan jual beli. Begitu juga tidak halal pinjaman yang disyaratkan dengan pembayaran jasa (al-ijârah) sebagaimana yang terdapat pada dana talangan haji. $\mathrm{Hal}$

\footnotetext{
${ }^{24}$ Abdurahman, "Dana Talangan Haji Haram dan Mudharat", dalam http://www.globalmuslim. web.id/2013/03/, diunduh 23 Desember 2012.

${ }^{25} \mathrm{Hafidz}$ Abdurahman, "Dana Talangan Haji Haram dan Mudharat", dalam http://www.globalmuslim. web.id/2013/03/, diunduh 23 Desember 2012.

${ }^{26} \mathrm{Hafidz}$ Abdurahman, "Dana Talangan Haji Haram dan Mudharat", dalam http://www.globalmuslim. web.id/2013/03/, diunduh 23 Desember 2012.
} 
ini bertentangan dengan kaidah fikih, "Setiap pinjaman yang membawa manfaat (bagi pemberi pinjaman) adalah riba ${ }^{\text {"27. }}$.

Dalam dana talangan haji, pihak LKS yaitu perbankan syariah memberi pinjaman kepada nasabah dan mensyaratkan untuk mengurusi berkas-berkasnya sampai mendapatkan kursi haji. Semuanya itu dilakukan dengan imbalan sejumlah uang. Dengan demikian pihak LKS mendapatkan manfaat dari pinjaman yang diberikan kepada nasabah melalui jasa pengurusan sehingga uang jasa tersebut dapat dikategorikan sebagai riba. ${ }^{28}$ Pinjaman adalah kegiatan sosial yang bertujuan membantu sesama manusia. Hal ini dilakukan untuk mencari pahala dari Allah Swt. sehingga tidak boleh dimanfaatkan untuk mengambil keuntungan materi dari kegiatan tersebut ${ }^{29}$.

Keempat, menurut Ketua Pusat Studi Ekonomi Islam (PSEI) LPPM UNS, M Hudi Asrori. Ada dua hal terkait ibadah haji yaitu masalah ibadah dan masalah manajemen. Salah satu syarat haji, yaitu bagi orang yang mampu melaksanakan perjalanan, baik mampu secara finansial, fisik, maupun memiliki kemampuan biaya hidup untuk orang yang ditinggalkan. Berdasarkan hukum shar'̂̀, sistem talangan perlu dikoreksi kembali karena di antara wajib haji adalah istitâah atau mampu, sehingga apakah dengan dana talangan itu dia betulbetul mampu atau belum ${ }^{30}$.

Hudi berpendapat perlunya dikaji kembali dampak dana talangan terhadap mekanisme pelaksanaan ibadah haji. Dana talangan ada kemungkinan dapat menghalangi orang yang benar-benar mampu dan ingin berhaji tetapi ada masa tunggu yang panjang. Kondisi ini bisa mengacaukan sistem haji. Seharusnya ada prioritas bagi orang yang benar-benar mampu. Apabila ada seseorang yang bisa membayar Rp 25 juta secara cash maka dia harus mendapat kesempatan lebih dulu untuk berangkat ibadah haji ${ }^{31}$.

Kelima, menurut Khairul Muttaqin. Walaupun tidak ada penegasan tentang larangan haji dengan dana utang, persoalannya adalah pelunasan utang yang disertai tambahan. Akad dana talangan mengandung riba bila dalam pelunasannya terdapat selisih. Fakta di lapangan menunjukkan bahwa calon haji diwajibkan membayar utang beserta tambahan uang dengan besaran yang berbeda-beda, cicilan yang sama, dan pelunasan dengan

\footnotetext{
${ }^{27} \mathrm{Http} / / /$ Ahmadzain.com, diunduh 25 Desember 2012.

${ }^{28} \mathrm{Http}: / /$ Ahmadzain.com, diunduh 25 Desember 2012.

${ }^{29} \mathrm{Http}: / /$ Ahmadzain.com, diunduh 25 Desember 2012.

${ }^{30}$ Koran Harian Umum Solopos, 20 April 2012.

${ }^{31}$ Koran Harian Umum Solopos, 20 April 2012.
}

tenor yang sama. Konsekuensi utang-piutang adalah berorientasi sosial (tabarru') bukan transaksi komersial. Dalam akad al-qard tidak diperbolehkan adanya tambahan apalagi selisih atas pokok utang ${ }^{32}$. Selain itu ada juga beberapa hal yang perlu dipertanyakan kembali, yaitu apa maksud pengkategorian al-ijârah oleh DSN?; Pihak bank menerima ujrah (fee) atas jasa apa?; Apakah ujrah tersebut atas jasa bank karena menalangkan dananya kepada nasabah?; Jasa apa yang dilakukan pihak bank? Padahal, yang mengurusi proses pendaftaran dan pengurusan lainnya adalah calon jamaah haji dan bukan pihak bank. ${ }^{33}$

Dalam talangan haji terjadi pergeseran makna istitâ'ah dari kemampuan secara material dan spiritual menjadi kemampuan mencicil dan melunasi utang. Padahal semestinya umat Islam yang mendambakan beribadah haji menabung sedikit demi sedikit ${ }^{34}$. Atas dasar itu maka umat Islam tidak sepatutnya memaksakan diri menunaikan ibadah haji dengan melakukan pelbagai macam cara seperti mengajukan pembiayaan ke perbankan syariah melalui dana talangan haji bilamana belum terpenuhi syarat menunaikan ibadah haji ${ }^{35}$.

Keenam, Muhammad Shiddiq al-Jawi mengharamkan dana talangan haji dengan beberapa alasan. Pertama, dalil yang digunakan untuk membolehkan dana talangan haji tidak tepat digunakan untuk membolehkan akad qard wa ijârah, Sebab dalil tersebut hanya membolehkan qard dan ijârah secara terpisah sehingga tidak tepat digunakan untuk membolehkan qard dan ijârah secara bersamaan dalam satu akad. ${ }^{36}$ Kedua, penggabungan dua akad menjadi satu akad sendiri hukumnya tidak boleh. Meskipun sebagian ulama membolehkan, seperti Imâm Ibn Taymiyyah (ulama Hanâbilah) dan ulama Mâlikiyah, tetapi pendapat yang râjih adalah pendapat yang tidak membolehkan, yakni pendapat jumhur ulama empat mazhab yakni ulama Hanafiyah, Mâlikiyah, Shafi'iyah, dan Hanâbilah. ${ }^{37}$ Ketiga, menurut ulama yang membolehkan penggabungan dua akad pun penggabungan qard dan ijârah termasuk akad yang

${ }^{32}$ Muhammad Khairul Muttaqin, "Dana Talangan Haji Riba", dalam Koran Harian Umum Republika, 9 Maret 2013.

${ }^{33}$ Muhammad Khairul Muttaqin, "Dana Talangan Haji Riba", dalam Koran Harian Umum Republika, 9 Maret 2013.

${ }^{34}$ Muhammad Khairul Muttaqin, "Dana Talangan Haji Riba", dalam Koran Harian Umum Republika, 9 Maret 2013.

${ }^{35}$ Muhammad Khairul Muttaqin, "Dana Talangan Haji Riba", dalam Koran Harian Umum Republika, 9 Maret 2013.

${ }^{36} \mathrm{Http}: / /$ www.khilafah1924.org, diunduh tanggal 10 Maret 2013.

${ }^{37} \mathrm{Http} / / /$ www.khilafah1924.org, diunduh tanggal 10 Maret 2013. 
tak dibolehkan. ${ }^{38}$ Keempat, akad qard wa ijârah tidak memenuhi syarat ijârah, sebab dalam akad ijârah disyaratkan objek akadnya bukan jasa yang diharamkan. ${ }^{39}$ Kelima, objek akad dalam qard wa ijârah adalah jasa qard dengan mensyaratkan tambahan imbalan. Hal ini tidak diperbolehkan karena setiap qard (pinjaman) yang mensyaratkan tambahan adalah riba, meskipun besarnya tidak didasarkan pada jumlah dana yang dipinjamkan. Kaidah fikih menyebutkan, "Kull qard sharata fîh an yazîdah fahuwa harâm bighayr khilâf(setiap pinjaman yang mensyaratkan tambahan hukumnya haram tanpa ada perbedaan pendapat)" 40 .

Berdasarkan uraian di atas maka jelaslah bahwa produk dana talangan haji, meskipun mempunyai landasan shar'î yang kuat dalam fatwa ulama DSN-MUI yang kemudian diperkuat oleh ijtimak ulama tetap masih menyisakan perdebatan di kalangan masyarakat. Pihakpihak yang tidak setuju (kontra) mengajukan keberatan dengan pelbagai macam argumen baik argumen teoretis maupun praktis. Terlepas dari adanya perbedaan pendapat tersebut, produk ini tetap ada dan tidak dilarang oleh pemerintah, dalam hal ini Kementerian Agama RI dan Bank Indonesia. Sebab, dalam bidang muamalah atau ekonomi Islam sudah disepakati landasannya adalah fatwa ulama yang tergabung dalam DSN-MUI. Selama fatwa ulama membolehkan maka selama itu pula produk tersebut tetap eksis. Meskipun demikian, argumentasi kelompok yang tidak setuju tetap perlu diapresiasi dan dijadikan bahan kajian lebih lanjut, khususnya secara akademis.

\section{Implementasi Dana Talangan Haji di Perbankan Syariah}

Dana talangan haji merupakan salah satu produk pembiayaan perbankan syariah yang diperuntukkan untuk memberi kemudahan kepada umat Islam dalam menunaikan ibadah haji. Produk pembiayaan ini diberikan untuk melayani calon jamaah haji reguler dan calon jamaah haji plus (khusus). Produk ini terbuka untuk semua kalangan. Disamping itu, produk ini juga diberikan bukan saja untuk membantu pembiayaan haji, tetapi juga umrah sehingga ada dana talangan haji dan dana talangan umrah.

Sasaran produk ini adalah nasabah perorangan dengan pelbagai macam profesi. Pihak bank bekerja

\footnotetext{
${ }^{38} \mathrm{Http}: / /$ www.khilafah1924.org, diunduh tanggal 10 Maret 2013.

${ }^{39} \mathrm{Http} / / /$ www.khilafah1924.org, diunduh tanggal 10 Maret 2013.

${ }^{40} \mathrm{Http}: / /$ www.khilafah1924.org, diunduh tanggal 10 Maret 2013.
}

sama dengan pihak lain seperti Kelompok Bimbingan Ibadah Haji (KBIH), komunitas pengajian, tokohtokoh agama dan sebagainya. Dengan adanya produk ini umat Islam diharapkan akan lebih mudah menunaikan rukun Islam yang kelima yaitu ibadah haji.

Produk ini lahir berdasarkan fatwa DSN-MUI Nomor: 29/DSN-MUI/VI/2002. Dalam fatwa tersebut produk ini diberi nama Pembiayaan Pengurusan Haji Lembaga Keuangan Syariah. Dalam praktiknya di perbankan syariah, produk ini diberi nama dengan nama yang berbeda sebagaimana terlihat dalam tabel berikut ini:

\begin{tabular}{|c|c|c|}
\hline No. & Nama Bank & Nama Produk \\
\hline 1. & BNI Syariah & Pembiayaan Haji \\
\hline 2. & $\begin{array}{l}\text { Bank Syariah } \\
\text { Mandiri }\end{array}$ & Pembiayaan Talangan Haji \\
\hline 3. & BRI Syariah & $\begin{array}{l}\text { Pembiayaan Pengurusan } \\
\text { Ibadah Haji }\end{array}$ \\
\hline 4. & $\begin{array}{l}\text { Bank Muamalat } \\
\text { Indonesia }\end{array}$ & Dana Talangan Porsi Haji \\
\hline 5. & Bank DKI Syariah & $\begin{array}{l}\text { Pembiayaan Pengurusan Haji } \\
\text { iB (Talangan Haji) Bank DKI } \\
\text { Syariah }\end{array}$ \\
\hline 6. & Bank BJB Syariah & $\begin{array}{l}\text { Dana Talangan Haji iB } \\
\text { Mashlahah }\end{array}$ \\
\hline
\end{tabular}

Pemberian nama tersebut memberikan aksentuasi yang berbeda-beda walaupun tujuannya sama. BNI Syariah lebih menekankan pada aspek pembiayaan haji, begitu juga dengan Bank DKI Syariah dan BRI Syariah. Hanya saja kedua bank terakhir ini lebih menekankan pada aspek jasa pengurusan haji yakni pendaftaran haji ke SISKOHAT Kementerian Agama untuk mendapatkan nomor seat haji. Sisanya lebih menekankan pada aspek jasa talangannya seperti Bank Syariah Mandiri, Bank Muamalat Indonesia, dan Bank BJB Syariah.

Besaran dana talangan yang diberikan perbankan syariah berbeda-beda sesuai dengan kebijakan bank masing-masing sebagaimana terlihat dalam tabel berikut ini.

\begin{tabular}{cll}
\hline No. & Nama Bank & Jumlah Maksimal \\
\hline 1. & BNI Syariah & Rp 23.750.000,- \\
\hline 2. & Bank Syariah Mandiri & $R p 22.500 .000,-$ \\
\hline 3. & BRI Syariah & $R p 23.000 .000,-$ \\
\hline
\end{tabular}




\begin{tabular}{lll}
\hline 4. & $\begin{array}{l}\text { Bank Muamalat } \\
\text { Indonesia }\end{array}$ & $\mathrm{Rp} \mathrm{24.500.000,-}$ \\
\hline 5. & Bank DKI Syariah & $\mathrm{Rp} 25.000 .000,-$ \\
\hline 6. & Bank BJB Syariah & $\mathrm{Rp} \mathrm{23.750.000,-}$ \\
\hline
\end{tabular}

Berdasarkan tabel tersebut, jelaslah bahwa ada pihak bank syariah yang memberikan dana talangan haji sampai $100 \%$ yaitu Rp 25.000.000,- seperti yang dilakukan oleh Bank DKI Syariah. Ini merupakan jumlah talangan tertinggi yang diberikan oleh bank syariah sehingga nasabah cukup menyediakan saldo minimal di buku tabungannya dan membayar ujrah karena setoran awal BPIH semuanya sudah ditalangi oleh pihak bank. Sementara itu yang paling kecil memberikan talangan maksimal adalah Bank Syariah Mandiri yaitu sebesar Rp 22.500.000,-.

Pihak bank diperbolehkan mempersyaratkan adanya jaminan $(\mathrm{rahn})$ karena dana talangan haji ini statusnya sebagai pinjaman. Jenis jaminannya ada dua macam yaitu jaminan pokok dan jaminan tambahan. Semua bank syariah menjadikan seat haji sebagai jaminan pokok sehingga apabila nasabah tidak mampu melunasi pinjaman tersebut maka seat tersebut dapat dibatalkan dan dikembalikan ke Kementerian Agama. Oleh karena itu, berkas yang harus ditandatangani oleh nasabah adalah surat kuasa kepada pihak bank untuk membatalkan seat haji nasabah jika nasabah tidak dapat melunasi pinjaman tersebut.

Adapun untuk jaminan tambahan maka perbankan syariah menerapkan kebijakan yang berbada-beda. BNI Syariah dan Bank Syariah Mandiri menerapkan kebijakan adanya jaminan tambahan, sedangkan Bank DKI Syariah dan Bank BJB Syariah tidak. Kedua bank terakhir menganggap cukup jaminannya pada seat haji nasabah, sedangkan kedua bank sebelumnya tidak demikian. Kedua bank tersebut tetap memerlukan adanya jaminan tambahan. Bank Syariah Mandiri menghendaki jaminannya berupa aset liquid yaitu aset yang mudah dicairkan ketika dibutuhkan seperti BPKB, emas, dan sebagainya, sedangkan Bank BNI Syariah jaminan tambahannya cukup berupa aset yang berharga sesuai dengan besarnya dana talangan yang diberikan seperti sertifikat rumah, tanah, dan sebagainya.

Jangka waktu pelunasan dana talangan haji berbedabeda sesuai dengan kebijakan masing-masing bank. Paling lama lima tahun yang dapat dicicil selama 60 bulan dan umumnya tiga tahun yang dapat dicicil selama 36 bulan. Lamanya waktu pelunasan mempengaruhi besaran ujrah yang harus dibayar oleh nasabah. Semakin lama waktu pelunasan maka semakin besar jumlah ujrah yang harus dibayar oleh nasabah sebagaimana ilustrasi yang terdapat dalam tabel berikut ini.

\begin{tabular}{|c|c|c|c|c|}
\hline \multirow{2}{*}{ No. } & \multirow{2}{*}{$\begin{array}{l}\text { Jumlah Dana } \\
\text { Talangan }\end{array}$} & \multicolumn{3}{|c|}{ Besaran Ujrah } \\
\hline & & Satuan Tahun & Dua Tahun & Tiga Tahun \\
\hline 1. & Rp 10.000.000,- & Rp 800.000,- & Rp 1.600.000,- & Rp 2.600.000, \\
\hline 2. & Rp 15.000.000,- & Rp 1.200.000,- & Rp 2.400.000,- & Rp 3.600.000, \\
\hline 3. & Rp 20.000.000,- & Rp 1.600.000,- & Rp 3.200.000,- & Rp 4.800.000. \\
\hline 4. & Rp 23.750.000,- & Rp 1.900.000,- & Rp 3.800.000,- & Rp 5.700.000. \\
\hline
\end{tabular}

Tidak semua bank syariah menerapkan kebijakan tersebut. Bank BNI Syariah menerapkan kebijakan yang tetap (flat) untuk ujrah yang harus dibayar oleh nasabah. Dana talangan reguler sebesar Rp 23.750.000,dikenakan ujrah sebesar Rp 2. 493.750,- dan talangan haji plus sebesar Rp 32.500,000,- dikenakan ujrah sebesar Rp 3.250.000,-. Bank Muamalat menetapkan ujrahnya tetap sebesar Rp 2.500.000,-, kemudian saat ini naik menjadi Rp 5.000.000,-. Bank DKI Syariah ujrah-nya Rp 1.900.000,- per tahun, sehingga bila dua tahun maka ujrah-nya sebesar Rp 3.800.000,. Perbedaan jumlah ujrah yang disebabkan besarnya dana talangan yang diberikan jelas merupakan salah satu penyimpangan dari fatwa DSN butir keempat yang berbunyi, "Besar imbalan jasa al-ijârah tidak boleh didasarkan pada jumlah talangan al-qard yang diberikan LKS kepada nasabah". Dengan demikian, hanya dua bank syariah yang penetapan besaran ujrahnya tidak menyimpang dari fatwa DSN tersebut yaitu Bank BNI Syariah dan Bank Muamalat. Sedangkan empat bank syariah lainnya tidak sesuai.

Sambil menunggu pengumuman pelunasan BPIH dari Kemenag, pelunasan talangan haji tidak menggunakan angsuran melainkan dengan cara menabung. Untuk menabung nasabah bisa menggunakan tabungan dengan mendebet dari saldo rekening tabungan. Hal ini yang membedakan produk dana talangan haji dengan produk pembiayaan lainnya. Pada produk pembiayaan lain nasabah diharuskan mengembalikan pinjaman beserta tambahan margin yang telah ditentukan oleh bank. Sedangkan pada produk dana talangan haji nasabah hanya mengembalikan dana sebesar pinjamannya tanpa ada tambahan margin melainkan hanya dibebankan biaya ujrah.

Menurut Anggito Abimanyu, akibat lamanya waktu pelunasan yang diberikan oleh pihak bank syariah maka produk ini tidak tepat dinamakan "talangan", tetapi lebih tepat "pembiayaan". Sebab talangan merupakan produk bank untuk jangka pendek seperti satu tahun, sedangkan pembiayaan merupakan produk bank untuk jangka relatif lama seperti 2-5 tahun. Atas dasar itu, 
Kementerian Agama menerapkan kebijakan baru untuk pelunasan dana talangan selama satu tahun dan mulai berlaku sejak tahun 2013. Ketentuan ini harus dipatuhi oleh perbankan syariah ${ }^{41}$. Apabila tidak dipatuhi maka bank syariah tersebut akan dicoret dari daftar nama bank yang berhak menerima setoran haji.

Akad yang digunakan dalam produk dana talangan haji bervariasi, ada yang menggunakan akad qard, akad ijârah, dan akad qard wal-ijârah sebagaimana terlihat dalam tabel berikut ini:

\begin{tabular}{cll}
\hline No. & Nama Bank & Akad \\
\hline 1. & BNI Syariah & al-Ijârah \\
\hline 2. & Bank Syariah Mandiri & al-Qard wal-ijârah \\
\hline 3. & BRI Syariah & al-Qard wal-Ijârah \\
\hline 4. & Bank Muamalat Indonesia & al-qard \\
\hline 5. & Bank DKI Syariah & al-Qard wal-Ijârah \\
\hline 6. & Bank BJB Syariah & al-Qard \\
\hline
\end{tabular}

Berdasarkan tabel tersebut terdapat tiga bank yang akad dana talangan hajinya sesuai denga fatwa DSN MUI yaitu Bank Syariah Mandiri, BRI Syariah, dan Bank DKI Syariah. Sedangkan tiga bank lainnya tidak sesuai ${ }^{42}$. Fatwa DSN menghendaki akadnya adalah qard wa al-ijârah sebagaimana bunyi diktum fatwa tersebut: Pertama, dalam pengurusan haji bagi LKS, dapat memperoleh imbalan jasa (ujrah) dengan menggunakan prinsip al-ijârah sesuai Fatwa DSN-MUI No.9/DSNMUI/IV/2000. Kedua, apabila diperlukan, LKS dapat membantu menalangi pembayaran BPIH nasabah dengan menggunakan prinsip al-qard sesuai Fatwa DSN-MUI No.19/DSN- MUI/IV/2001.

Secara umum persyaratan untuk mendapatkan pembiayaan dana talangan haji dari perbankan syariah adalah sama. Pertama, minimal berusia 21 tahun yang menunjukkan usia dewasa menurut undang-

${ }^{41}$ Lihat Keputusan Direktur Jenderal Penyelenggaraan Haji dan Umrah No. D/303 Tahun 2013 tentang Petunjuk Teknis Pelaksanaan Ketentuan Bank Penerima Setoran Biaya Penyelenggaraan Ibadah Haji, Bab I Persyaratan Bank Penerima Setoran Biaya Penyelenggaraan Ibadah Haji, ayat (3) butir butir (g) Yang berbunyi, "Surat pernyataan dari Direksi bahwa tidak akan melanggar ketentuan tentang pemberian dana talangan haji atau dana sejenisnya termasuk pemberian penyaluran dana (linkages) untuk talangan haji yang diberikan kepada lembaga keuangan atau pihak ketiga lainnya".

${ }^{42}$ Di BPD Syariah DIY akad yang digunakan adalah al-ijârah multijasa. Lihat, Talabah Pendidikan Ulama Tarjih Muhammadiyah Putra Yogyakarta, "Dana Talangan Haji: Problem dan Hukumnya", dalam Tarjih, Jurnal Tarjih dan Tajdid, Edisi ke-11 No.1 Tahun 2013, h. 86-87. undang. Dengan perkataan lain nasabahnya harus sudah dewasa. Kedua, mempunyai penghasilan tetap yang dibuktikan dengan surat asli keterangan kerja, fotokopi SK pengangkataan dan slip gaji bagi karyawan atau pegawai. Sementara itu, bagi profesional atau wiraswasta melampirkan fotokopi SIUP/SITU/Surat Izin Praktek dan Akta pendirian perusahaan. Ketiga, identitas nasabah yang meliputi fotokopi KTP suamiisteri, surat nikah, dan kartu keluarga. Keempat, membuka rekening tabungan haji di bank syariah.

Adapun langkah-langkah pendaftaran haji dengan menggunakan dana talangan haji di perbankan syariah. Pertama, nasabah calon jamaah haji pergi ke bank syariah untuk mengajukan permohonan dana talangan haji dengan mengisi form pendaftaran. Kedua, melakukan proses akad yang disepakati bersama antara pihak bank dengan nasabah. Ketiga, setelah saldo di rekening mencapai Rp 25.500.000 kemudian didaftarkan ke Kementerian Agama untuk mendapatkan nomor SPPH. Keempat, SPPH dari Kemenag dibawa kembali ke bank untuk didaftarkan melalui SISKOHAT guna mendapatkan porsi haji. Kelima, hasil inputan SPPH berupa BPIH. Keenam, BPIH tersebut dikembalikan lagi ke Kemenag untuk didaftar ulang oleh pihak bank.

Berdasarkan uraian di atas jelas telah terjadi penyimpangan implementasi dana talangan haji di perbankan syariah. Paling tidak terdapat dua bentuk penyimpangan. Pertama, penggunaan akad dalam produk dana talangan haji yang semestinya menggunakan akad al-qard wa al-ijârah, tetapi dalam praktiknya menggunakan akad yang lain seperti akad al-qard atau akad al-ijârah saja. Kedua, penentuan besarnya ujrah mestinya tetap (flat) dan tidak ditentukan berdasarkan besarnya dana talangan yang diberikan, tetapi dalam praktiknya tidak demikian.

Atas dasar itu maka pemerintah, dalam hal ini Kementerian Agama, menetapkan persyaratan produk dana talangan haji di perbankan syariah harus memenuhi persyaratan sebagai berikut: Pertama, sesuai dengan fatwa DSN MUI. Kedua, jangka waktu dana talangan maksimal 1 (satu) tahun dan tidak dapat diperpanjang (roll-over). Ketiga, ujrah yang dikenakan kepada calon jemaah bersifat nominal dan tetap ( $f(x)$, serta tidak dikaitkan dengan persentase tertentu pemberian dana talangan. ${ }^{43}$

${ }^{43}$ Lihat Keputusan Direktur Jenderal Penyelenggaraan Haji dan Umrah No. D/303 Tahun 2013 tentang Petunjuk Teknis Pelaksanaan Ketentuan Bank Penerima Setoran Biaya Penyelenggaraan Ibadah Haji Bab I Persyaratan Bank Penerima Setoran Biaya Penyeelenggaraan Ibadah Haji, ayat (6). 
Di samping itu, pemberian dana talangan yang mencapai $100 \%(\mathrm{Rp} 25.000 .000,-)$ jelas tidak mendidik umat. Hal tersebut secara tidak langsung memaksa umat untuk memaksakan diri mendaftar haji meskipun secara finansial belum mampu (istitâah). Akibatnya umat yang belum terkena kewajiban haji memaksakan diri untuk pergi haji. Lalu pergi hajinya karena siapa, perintah Allah atau hawa nafsunya? Ali Mustafa Ya’qub menyebutnya bukan haji pengabdi Allah, melainkan haji "pengabdi setan". ${ }^{44}$ Jelas hal ini bertentangan dengan Alquran yang menetapkan kewajiban haji hanya bagi umat Islam yang mampu dan dilakukan semata-mata karena memenuhi panggilan Allah.

\section{Pengaruh Dana Talangan Haji}

Besarnya antusiasme masyarakat untuk mendaftar haji memang tidak bisa dilepaskan dari dana talangan haji yang ditawarkan pihak bank kepada mereka yang punya keinginan untuk naik haji. Terlepas dari prokontra kebolehan dana talangan haji ini secara fikih, tetapi memang dampak psikologisnya begitu besar dirasakan.

Dengan adanya dana talangan haji, orang yang pada dasarnya belum mampu melaksanakan pendaftaran haji secara finansial dapat mendaftar dengan modal utang dari bank. Syarat untuk bisa mendaftar haji dan mendapatkan nomor porsi di Kementerian Agama yaitu menyetorkan uang sebesar 25 juta rupiah. Dengan adanya dana talangan haji maka seseorang bisa membayarkan setoran awal BPIH ke Kementerian Agama dan mencicilnya ke bank di kemudian hari.

Akibatnya, mereka yang sebenarnya mempunyai kemampuan finansial menjadi terhalang keberangkatan hajinya karena terlambat mendaftar dan membayarkan uang untuk nomor porsi haji. Padahal keterlambatan tersebut terjadi karena calon jamaah tersebut ingin menghindari utang sehingga ia melakukannya dengan cara menabung terlebih dahulu.

Menurut Ledia Hanifa, anggota Komisi VIII DPR RI, panjangnya antrean atau daftar tunggu calon jamaah haji disebabkan kemudahan fasilitas produk perbankan berupa dana talangan haji. Pelaksanaan ibadah haji telah membuka kesempatan bisnis, tidak terkecuali bagi pihak perbankan termasuk perbankan syariah. Dengan dana talangan haji, calon jamaah haji cukup menyetor

${ }^{44}$ Ali Mustafa Ya'qub, "Haji Utang dan Utang Haji", dalam Ali Rokhmad et.al., Dinamika dan Perspektif Haji Indonesia, (Jakarta: Direktorat Jenderal Penyelenggaraan Haji dan Umrah, 2010), h. 198 dan Ali Mustafa Ya’qub, Mewaspadai Provokator Haji, (Jakarta: Pustaka Firdaus, 2009), h. 81-88. sejumlah uang yang besarnya bervariasi kepada bank. Kemudian pihak bank menutupi kekurangan dana agar mereka dapat segera memperoleh nomor porsi kursi atau seat haji. Dalam praktik di lapangan, ada pihak bank yang memberikan kemudahan, yaitu dengan setoran awal Rp 500 ribu hingga Rp 2 juta seorang calon jamaah sudah bisa mendapat nomor porsi ${ }^{45}$.

Lebih lanjut Ledia menjelaskan bahwa produk dana talangan haji ini berkontribusi menambah panjang daftar tunggu calon jamaah haji. Pada satu sisi dana talangan haji memberikan kemudahan bagi masyarakat untuk mendaftar haji sampai mendapatkan porsi. Sementara itu, di sisi lain dana talangan ini malah memperpanjang masa tunggu calon jamaah haji yang memiliki kemampuan riil untuk membayar biaya hajiit ${ }^{46}$. Oleh karena itu, Anggota Komisi VIII Nasir Djamil mengusulkan agar dana talangan haji segera dievaluasi dalam waktu secepatnya ${ }^{47}$.

Dirjen Penyelenggaraan Haji dan Umroh Kementerian Agama RI, Anggito Abimanyu, menyampaikan hal yang sama tentang panjangnya daftar antrean jamaah haji disebabkan oleh pemanfaatan dana talangan haji. Menurut dia, selain tidak sesuai dengan prinsip haji, produk pembiayaan dana talangan haji juga telah membuat daftar antrean untuk naik haji semakin panjang. Akibatnya masyarakat yang telah memenuhi syarat kemampuan secara finansial harus menunggu bertahun-tahun untuk dapat menunaikan ibadah haji ${ }^{48}$.

Menurut Ketua Komisi VIII DPR, Ida Fauziah, ada potensi jumlah antrean jamaah haji akan terus meningkat. Salah satu penyebabnya adalah adanya praktik dana talangan haji. Saat ini bank-bank pemberi dana talangan rajin bergerilya mencari calon jamaah yang mau berutang untuk menunaikan rukun Islam yang kelima itu. Dalam praktik tersebut ada unsur tidak adil karena orang yang tidak memiliki uang bisa cepat mendaftar haji. Sementara itu, sebagian lagi bersusah payah menabung sampai memiliki uang cukup, baru mendaftar berhaji. Oleh karena itu, Komisi VIII sedang

${ }^{45} \mathrm{Hal}$ ini disampaikan Ledia Hanifa dalam Seminar "Dana Talangan Haji, Solusi atau Masalah?”, diselenggarakan oleh Fraksi PKS di ruang rapat pleno fraksi, Gedung Nusantara I, Kompleks Parlemen, Senayan, pada Kamis, tanggal 21 Maret 2013.

${ }^{46} \mathrm{Hal}$ ini disampaikan Ledia Hanifa dalam Seminar "Dana Talangan Haji, Solusi atau Masalah?”, diselenggarakan oleh Fraksi PKS di ruang rapat pleno fraksi, Gedung Nusantara I, Kompleks Parlemen, Senayan, pada Kamis, tanggal 21 Maret 2013.

${ }^{47} \mathrm{Hal}$ ini disampaikan Ledia Hanifa dalam Seminar "Dana Talangan Haji, Solusi atau Masalah?”, diselenggarakan oleh Fraksi PKS di ruang rapat pleno fraksi, Gedung Nusantara I, Kompleks Parlemen, Senayan, pada Kamis, tanggal 21 Maret 2013.

${ }^{48}$ Republika.co.id, diunduh pada 22 Maret 2013. 
menunggu hasil kajian soal dana talangan ini ${ }^{49}$.

Selama ini dana talangan haji telah menyebabkan kenaikan nilai pembiayaan atau kredit, baik di bank konvensional maupun bank syariah. Dana talangan haji juga telah memberikan dampak membludaknya jumlah calon jamaah haji yang mendaftar. Hal tersebut berakibat pada daftar antrean tunggu calon jamaah haji (waiting list) yang semakin panjang. Rencana pelarangan dana talangan haji ke depan diharapkan dapat menurunkan nilai pembiayaan/kredit, baik di bank konvesional maupun bank syariah.

Sebelum pemberlakuan sistem waiting list, jumlah jamaah haji Indonesia tidak pernah menembus 210 ribu jemaah karena sistem pendaftaran sangat singkat dan praktis bagi mayoritas umat Islam. Jamaah yang berangkat benar-benar berkemampuan sesuai kriteria syariat. Ledakan pendaftar baru terjadi pada tahun 2009. Pada tahun itu, jumlah waiting list mencapai 800.000 orang, tahun 2010 berjumlah 1.200 .000 orang, tahun 2011 berjumlah 1.400 .000 orang dan tahun 2012 mencapai 1.900 .000 orang. Dengan demikian, kecenderungannya semakin meningkat padahal kuota haji per tahun hanya sekitar 211.000 jamaah. Adanya penambahan pendaftaran calon jamaah haji yang signifikan, tetapi tidak berbanding lurus dengan kuota yang ada mengakibatkan terjadinya penumpukan calon jamaah haji yang membutuhkan waktu antrean selama 10-15 tahun $^{50}$.

Sementara itu Majelis Ulama Indonesia (MUI) tidak melihat adanya korelasi antara produk talangan haji yang saat ini ada di perbankan syariah dengan panjangnya antrean calon jamaah haji di Kementerian Agama. Oleh karena itu, menurut Gunawan Yasni, anggota DSN-MUI, upaya yang bisa dilakukan oleh pemerintah untuk memperpendek antrean adalah dengan moratorium ${ }^{51}$.

Nadratuzzaman Hosen, Bendahara MUI, sependapat dengan Gunawan Yasni. Menurut dia, produk talangan haji tidak bisa dijadikan alasan yang mengakibatkan perpanjangan antrean haji. Pemerintah seharusnya melakukan penghentian sementara rekrutmen calon jamaah haji. Sebab tanpa talangan haji pun antrean daftar haji akan terus memanjang selama pemerintah tetap membuka pendaftaran. Oleh karena itu, K.H. Måruf Amin, selaku Ketua MUI, membantah anggapan bahwa dana talangan haji telah memperpanjang antrean.

49 www.lptqkabupatenlamandau.com, diunduh pada 22 Maret 2013.

${ }^{50}$ http://www.change.org, diunduh pada 23 Maret 2013.

${ }^{51}$ http://www.jurnalhaji.com, diunduh pada 23 Maret 2013.
Menurut dia, penyebab antrean panjang para jamaah yang ingin menunaikan ibadah haji karena Kementrian Agama selalu membuka pendaftaran. Oleh karena itu, antrean menjadi panjang dan tidak terarah. Maka solusinya adalah melakukan moratorium pendaftaran haji meskipun dia tidak menghendaki saat ini ${ }^{52}$.

Menurut Agustianto, dana talangan haji yang dilakukan bank syariah memiliki multimaslahat bagi banyak pihak. Hal ini bermakna mendatangkan banyak manfaat dan kemaslahatan bagi umat Islam, rakyat (UKM), bangsa, negara, serta lembaga-lembaga keuangan syariah..$^{53}$

Menurut Zaim Saidi, praktik seperti ini hanya akan merugikan calon jamaah haji yang tidak bersedia melakukan pinjaman kepada bank. Sebab mereka yang mengambil pinjaman ini akan menggeser mereka yang antre sesuai dengan kemampuan setoran masingmasing. Sedangkan waktu tunggu saat ini sudah sangat panjang mencapai 7-8 tahun. Hal ini dinilai menimbulkan ketidakadilan. Skema pinjaman dana talangan haji sebenarnya merupakan utang yang harus dibayar dengan cara mengangsur. Hal ini menyalahi ketentuan ibadah haji yaitu syarat wajib haji yang berlaku hanya bagi mereka yang mampu ${ }^{54}$. Zaim Saidi lebih lanjut menjelaskan bahwa dalih perbankan yang menyatakan bahwa talangan diberikan kepada yang mampu adalah absurd. Kalau orang mampu tentu tidak butuh talangan atau pinjaman. Faktanya, justru sebaliknya, skema talangan akan membuat orang yang tidak mampu memaksa diri untuk menjadi mampu dengan meminjam pada bank. Dalih lain bahwa dana itu akan memperkuat perekonomian masyarakat juga tidak masuk akal. Yang jelas dana itu hanya akan menguntungkan perbankan saja dan tidak ada kaitannya dengan perekonomian masyarakat ${ }^{55}$.

Tidak bisa dipungkiri bahwa sebuah produk tentu memiliki sisi positif dan negatif. Manfaat utama dari produk ini adalah memberikan bantuan kepada masyarakat untuk melaksanakan salah rukun Islam yakni berhaji ke Baitullah, sehingga ia bisa saja dianggap sebagai bagian dari fath al-dharîah. Di samping itu, produk ini memiliki peminat yang cukup banyak sehingga berpotensi memajukan Lembaga Keuangan Syariah sebagai instrumen ekonomi umat Islam.

Kajian ulang terhadap produk dana talangan haji menghasilkan sebuah regulasi yang 'melarang' pemberian dana talangan oleh bank kepada calon jamaah haji

\footnotetext{
${ }^{52} \mathrm{http}: / /$ www.jurnalhaji.com, diunduh pada 23 Maret 2013.

53 http://kalbar.kemenag.go.id, diunduh pada 23 Maret 2013.

${ }^{54}$ www.hidayatullah.com, diunduh pada 25 Maret 2013.

${ }^{55}$ www.hidayatullah.com, diunduh pada 25 Maret 2013.
} 
secara bebas. Kementerian Agama menerapkan pembatasan dana talangan haji yang dituding sebagai penyebab panjangnya antrean haji. Bank Penerima Setoran (BPS) Biaya Penyelenggaraan Ibadah Haji (BPIH) boleh memberikan dana talangan haji, namun tidak boleh bersifat pinjaman. Dirjen Penyelenggara Haji dan Umrah, Anggito Abimanyu, menjelaskan bahwa dana talangan tidak boleh menjadi pembiayaan. Oleh karena itu maka dana talangan diberikan kepada calon jamaah yang sudah mendapatkan porsi untuk berangkat tahun tersebut namun kesulitan untuk melunasi kekurangan setoran BPIH. Bank diperbolehkan memberikan dana talangan kepada jamaah tersebut yang harus dikembalikannya dalam waktu maksimal satu tahun. Karena bukan pinjaman, dana talangan yang diberikan bank juga tidak boleh membebani warga ${ }^{56}$.

Dalam Permenag No. 30 Tahun 2013 tentang Bank Penerima Setoran Biaya Penyelenggaraan Ibadah Haji, Kemenag melarang perbankan memberikan dana talangan yang tidak sesuai dengan aturan ${ }^{57}$. Dana talangan hanya boleh diberikan sesuai aturan yakni selama satu tahun ${ }^{58}$.

Permenag tersebut sebenarnya tidak bermaksud melarang dana talangan haji karena landasan shar' $\hat{\imath}^{-}$ nya sangat kuat berupa fatwa DSN-MUI yang diperkuat oleh putusan Ijtimak Ulama Komisi Fatwa seluruh Indonesia. Lebih dari itu, ternyata fatwa-fatwa tersebut didukung oleh teks-teks Alquran dan Hadis serta qawâid fiqhiyyah yang memadai. Oleh karena itu, fatwa-fatwa tersebut mencerminkan pendapat mayoritas ulama Indonesia (jumhur ulama) meskipun ada sebagian ulama yang tidak sependapat.

Permenag tersebut hanya membatasi pemberian dana talangan haji untuk meluruskan kekeliruan dalam praktiknya di perbankan syariah baik menyangkut jangka waktu pengembalian maupun akadnya. Dalam implementasinya di lapangan, dana talangan tersebut diberikan untuk melunasi BPIH bukan untuk memperoleh seat haji. Dengan demikian, Permenag tersebut mencoba mengambil jalan tengah. Di satu sisi dana talangan tersebut mendatangkan maslahat, sedangkan di sisi lain mendatangkan madarat. Oleh karena itu, memperhatikan madarat atau mafsadah dana talangan haji harus didahulukan sesuai dengan kaidah usul fikih yang berbunyi, ${ }^{59}$

\footnotetext{
${ }^{56}$ www.hidayatullah.com, diunduh pada 25 Maret 2013.

${ }^{57}$ http://www.hukumonline.com, diunduh pada 25 Maret 2013.

${ }^{58}$ Pasal 2 ayat (2) butir (g) PMA No.30 tentang Persyaratan Bank Syariah Penerima BPIH

59 'Alî Ahmad al-Nadwî, Al-Qawâid al-Fiqhiyyah; Mafhûmuhâ, Nash'atuhâ, Tatawwuruhâ, Dirâsah Mu'allafâtuhâ, Adillatuhâ, Muhimmatuhâ, Tatbîquhâ, h. 272
}

(Menolak kemudaratan lebih diutamakan dari pada mencari kemaslahatan).

\section{Penutup}

Dana talangan haji yang menjadi salah satu produk pembiayaan pada perbankan syariah mempunyai landasan shar'î berupa fatwa DSN yang diperkuat oleh ijtimak ulama Komisi Fatwa seluruh Indonesia. Fatwa tersebut merujuk pada ayat-ayat dan Hadishadis Nabi Saw. serta qawẩid fiqhiyyah yang menjadi dasar transaksi ijârah dan qard. Hal ini mencerminkan pendapat mayoritas ulama Indonesia (jumhur ulama). Oleh karena itu, dana talangan haji mempunyai landasan shar'î yang kuat.

Dalam implementasinya, dana talangan haji diberikan kepada nasabah yang mampu melunasi dana talangan sebelum berangkat ke tanah suci. Dengan demikian, nasabah itu sudah termasuk istitâah. Akad yang digunakan oleh perbankan syariah ternyata berbeda-beda. Ada yang menggunakan akad ijârah, qard, dan gabungan antara keduanya. Akad ijârah digunakan karena menyangkut penyewaan seat haji dari bank syariah kepada nasabah sehingga bank berhak mendapat ujrah. Sedangkan akad qard menyangkut pembayaran dana talangan yang telah dikeluarkan bank syariah untuk mendapat seat haji yang harus dilunasi oleh nasabah dalam jumlah yang sama dan tidak ada penambahan.

Dana talangan haji pada satu sisi memberikan dampak positif (maslahah), sedangkan pada sisi yang lain memberikan dampak negatif (mafsadah). Dampak positifnya memberikan kemudahan kepada nasabah dalam pendaftaran haji untuk mendapatkan seat haji. Bank-bank syariah pun semakin berkembang karena hadirnya pembiayaan ini yang disambut antusias oleh sebagian besar nasabah. Sementara itu, dampak negatif dana talangan haji ini adalah semakin mengaburkan kriteria istitâah yang menjadi persyaratan wajib haji. Di samping itu, pembiayaan ini berkontribusi dalam memperpanjang waiting list keberangkatan haji dan menimbulkan ketidakadilan karena menutup kesempatan mereka yang tidak menggunakan jasa dana talangan.[]

\section{Pustaka Acuan \\ Buku:}

Bukhârî, al-, Sahîh al-Bukhârî, al-Qâhirah: Dâr alHadîth, 2004.

Mubarok, Jaih dan Hasanudin, "Fatwa tentang Pembiayaan Pengurusan Dana Haji dan Status Dana Calon Haji Daftar Tunggu", dalam Al-Iqtishad, Jurnal 
Ilmu Ekonomi Syariah, Fakultas Syariah dan Hukum kerjasama dengan Ikatan Ahli Ekonomi Islam Indonesia, Vol. V No.1, edisi Januari 2013.

Musannaf Ibn Abî Shaybah dalam Maktabah Shâmilah. Muslim, Imâm, al-Jâmi al-Sahîh, Bayrût: Dâr al-Fikr, t.th.

Nadwî, al-,'Alî Ahmad, Al-Qawâid al-Fiqhiyyah; Mafhîmuhâ, Nash'atuhâ, Tatawwuruhâ, Dirâsah Mu'allafâtuhâ, Adillatuhâ, Muhimmatuhâ, Tatbîquhâ, Damaskus: Dâr al-Qalam, 1994.

Putuhena, M. Shaleh, Historiografi Haji Indonesia, Yogyakarta: LkiS, 2007.

Sam, Ikhwan, et. al., Himpunan Fatwa Dewan Syariah Nasional, Jakarta: Dewan Syariah Nasional MUI dan Bank Indonesia, 2006.

Suyûtî, al-, Al-Ashbah wa al-Nazâir fî al-Furû', Bayrût: Dâr al-Fikr, t.th.

Talabah Pendidikan Ulama Tarjih Muhammadiyah Putra Yogyakarta, "Dana Talangan Haji: Problem dan Hukumnya", dalam Tarjih, Jurnal Tarjih dan Tajdid, Edisi ke-11 No.1 Tahun 2013.

Tirmîdhî, al-, Sunan al-Tirmîdhî, Bayrût: Dâr al-Fikr, 2003.

Ya’qub, Ali Mustafa, "Haji Utang dan Utang Haji", dalam Ali Rokhmad et.al., Dinamika dan Perspektif Haji Indonesia, Jakarta: Direktorat Jenderal Penyelenggaraan Haji dan Umrah, 2010.

Ya'qub, Ali Mustafa, Mewaspadai Provokator Haji, Jakarta: Pustaka Firdaus, 2009.

Zuhaylî, al-, Wahbah, Usûl al-Fiqh al-Islâmî, Bayrût: Dâr al-Fikr al-Mu’âsir, 1986.

\section{Website dan Artikel Media Massa:}

Abdurahman, Hafidz, "Dana Talangan Haji Haram dan Mudharat", dalam http://www.globalmuslim. web.id/2013/03/, diunduh 23 Desember 2012.

Muttaqin, Muhammad Khairul, "Dana Talangan Haji Riba", dalam Koran Harian Umum Republika, 9 Maret 2013.

Koran Harian Umum Republika, 20 Nopember 2012. Koran Harian Umum Republika.co.id, diunduh pada 22 Maret 2013.

Koran Harian Umum Solopos, 20 April 2012.

www.ahmadzain.com, diunduh 25 Desember 2012.

www., diunduh pada 23 Maret 2013.

www.news.detik.com, diunduh pada 23 Desember 2012. www.news.detik.com/read/2012/02/21/181538/18482

42/10/berpotensi-korupsi-kpk-usulkan moratoriumpendaftaran-haji, diunduh pada 23 Desember 2012.

www.change.org, diunduh pada 23 Maret 2013.

www.hariansumutpos.com/2012/02/27081/daftar-hajitunggu-8-tahun-lagi.htm, diunduh pada 23 Desember 2012.

www.hukumonline.com, diunduh pada 25 Maret 2013. www.indopos.co.id/index.php/arsip-berita-nasional/75nasional-reviews/21934-komisi-viii-kritik-busyrosoal-moratorium-haji.html, diunduh pada 23 Desember 2012.

www.jurnalhaji.com, diunduh pada 23 Maret 2013. www.khilafah1924.org, diunduh tanggal 10 Maret 2013. www.hidayatullah.com, diunduh pada 25 Maret 2013. www.lptqkabupatenlamandau.com, diunduh pada 22 Maret 2013. 